\title{
PENANGGULANGAN SAMPAH DI MY DARLING
}

\author{
Oleh:
}

Destin Putri A., Nandang Mulyana, \& Nurliana Cipta Apsari

\begin{abstract}
ABSTRAK
Karya ilmiah yang berjudul Pengolahan Sampah ini membahas keseluruhan tentang solusi dari dua masalah. Masalah pencemaran lingkungan oleh sampah, dimana banyak sampah yang terbuang begitu saja sehingga sampah-sampah tersebut menumpuk dan menyebabkan pencemaran. Tujuan penulisan karya ilmiah ini adalah untuk menganalisa serta dapat meminimalisir sampah dari lingkungan. Metode yang digunakan dalam penulisan karya ilmiah ini adalah dengan melakukan Studi Pustaka dan Studi Lapangan. Studi Pustaka dilakukan dengan mencari bahan-bahan tentang pengolahan sampah melalui buku-buku yang bersifat ilmiah dan internet. Studi Lapangan dilakukan dengan mencari informasi-informasi dari beberapa ahli dan mempraktikkan cara pengolahan secara langsung. Tidak hanya itu, untuk memperkuat penelitian ini, kami juga melakukan pengamatan secara langsung dengan komunitas MY Darling Dengan pengamatan secara langsung terhadap peran pemerintah dan masyarakat akan upaya penanggulangan sampah. Kami juga melakukan wawancara, baik secara langsung kepada warga RW 11 Kelurahan Cibangkong, Kecamatan Batununggal, komunitas My Darling dan kepada Ibu Dewi Kusmianti ketua My Darling itu sendiri. Berdasarkan hasil penelitian, kami mengetahui bahwa penanggulangan sampah di Indonesia sendiri ternyata masih belum tercapai. Ini terus berlangsung sampai sekarang. Tetapi dengan adanya komunitas My Darling di harapkan bisa membantu menyadarkan masyarakat luas terhadap pentingnya menjaga agar lingkungan tidak semakin tercemar oleh sampah.
\end{abstract}

\section{ABSTRACT}

The scientific work entitled Waste discusses overall on the solution of two problems. Problems of environmental pollution by trash, where a lot of garbage thrown away that trash pile up and cause pollution. The purpose of writing this paper is to analyze and can minimize waste from the environment. The method used in the writing of this paper is to do a Library Studies and Field Studies. Library studies done by looking for materials on waste management through the books of a scientific nature and the internet. Field studies carried out by seeking information from several experts and practicing ways of processing directly. Not only that, to strengthen this study, we also observed directly with communities MY Darling With direct observation of the role of government and the public will waste reduction efforts. We also did an interview, either directly to citizens Village Cibangkong RW 11, District Batununggal, My Darling community and to the chairman of the Mother Goddess Kusmianti My Darling itself. Based on the research results, we know that waste reduction in Indonesia itself has not yet been reached. It continues today. But with the community My Darling is expected to help sensitize the public to the importance of keeping the environment from getting polluted by garbage

\section{PENDAHULUAN}

Permasalahan lingkungan merupakan isu yang tidak bisa di hindarkan. Saat ini sampah merupakan masalah lingkungan yang sangat serius yang di hadapi masyarakat Indonesia pada umumnya. Bisa dikatakan sampah setiap hari di hasilkan oleh ibu-ibu rumah tangga, Baik itu sampah organik maupun anorganik. 
Namun yang memprihatinkan, sampahsampah yang dihasilkan tersebut malah dibuang sembarangan di berbagai tempat, dan efeknya akan merusak lingkungan yang ada di sekitarnya. Jumlah produksi sampah setiap tahun akan bertambah seiring dengan bertambah jumlah penduduk. Pemerintah saat ini telah berupaya dengan berbagai cara untuk mengatasi masalah sampah. Terutama masalah sampah anorganik. Namun, belum mencapai titik kesempurnaan. Hal ini dikarenakan angka jumlah sampah yang ada di Indonesia sangat tinggi. Sehingga pemerintah kesulitan untuk menentukan cara yang tepat untuk menyelesaikannya.

Adapun yang menjadi tujuan dalam penulisan makalah ini yaitu agar :

1. Dapat Mengetahui Pengertian Sampah dan Daur Ulang Sampah.

2. Dapat Mengetahui Cara-Cara Pembuatan Daur Ulang Sampah

3. Dapat Mengetahui Manfaat Daur Ulang Sampah

4. Dapat Mengetahui Keuntungan Dan Kerugian Dalam Pembuatan Produk Daur Ulang Sampah.

\section{Pengertian sampah.}

Sampah adalah suatu bahan yang terbuang atau dibuang dari sumber hasil aktifitas manusia maupun alam yang belum memiliki nilai ekonomis. Sampah merupakan material sisa yang tidak diinginkan setelah berakhirnya suatu proses. Sampah merupakan didefinisikan oleh manusia menurut derajat keterpakaiannya, dalam proses-proses alam sebenarnya tidak ada konsep sampah, yang ada hanya produk-produk yang dihasilkan setelah dan selama proses alam tersebut berlangsung. Akan tetapi karena dalam kehidupan manusia didefinisikan konsep lingkungan maka Sampah dapat dibagi menurut jenis-jenisnya (Anonim:2012). Setiap tahun jumlah sampah di Indonesia pada umumnya selalu bertambah, seiring dengan bertambahnya jumlah penduduk serta penggunaan bahan-bahan yang menghasilkan banyak sampah secara berlebihan.

Jenis-jenis sampah berdasarkan sifatnya.

A. Sampah organik

Sampah Organik, yaitu sampah yang mudah membusuk seperti sisa makanan,sayuran, daun-daun kering, dan sebagainya.

B. Sampah anorganik

Sampah Anorganik, yaitu sampah yang tidak mudah membusuk, seperti plastik wadah pembungkus makanan, kertas, plastik mainan, botol dan gelas minuman, kaleng, kayu, dan sebagainya.

\section{Pengertian daur ulang sampah plastik.}

Berbicara masalah sampah, tentu yang ada dalam pikiran kita adalah sisa-sisa bahan yang tidak dipakai lagi, kotor dan berbau busuk serta tidak berguna. Namun anggapan seperti itu tidak selalu benar, sampah juga dapat dimanfaatkan untuk menjadi barang yang bernilai jual dan menguntungkan dengan cara daur ulang. Daur ulang (Recycle) sampah plastik adalah proses untuk menjadikan suatu bahan bekas menjadi bahan baru dengan tujuan mencegah adanya sampah yang sebenarnya dapat menjadi sesuatu yang berguna, mengurangi penggunaan bahan baku yang baru, mengurangi penggunaan energi, mengurangi polusi, kerusakan lahan, dan emisi gas rumah kaca jika dibandingkan dengan proses pembuatan barang baru. Daur ulang adalah salah satu strategi pengelolaan sampah padat yang terdiri atas kegiatan pemilahan, pengumpulan, pemrosesan, pendistribusian dan pembuatan produk / material bekas pakai, dan komponen utama dalam manajemen sampah modern dan bagian ketiga adalam proses hierarki sampah 3R (Reuse, Reduce,nandnRecycle). Sampai saat ini sampah plastic merupakan sampah yang belum diketahui cara penanggulangannya. Namun saat ini cara yang paling tepat adalah dengan 
mendaur ulang sampah-sampah tersebut menjadi suatu produk yang bernilai tinggi Proses atau Tahapan Daur Ulang. Berikut ini merupakan tahap-tahap dari kegiatan daur ulang:

1. Mencari barang-barang yang telah di buang seperti kertas, botol air mineral, dus susu, kaleng dan lain-lainya.

2. Memilah; yakni mengelompokkan sampah yang telah dikumpulkan berdasarkan jenisnya, seperti kaca, kertas, danplastik.

3. Menggunakan Kembali; Setelah dipilah, carilah barang yang masih bisadigunakan kembali secara langsung. Bersihkan terlebih dahulu sebelumdigunakan.

4. Mengirim; Kirim sampah yang telah dipilah ke tempat daur ulang sampah,atau menunggu pengumpul barang bekas keliling yang akan dengan senanghati membeli barang tersebut.

5. Lakukan Daur Ulang Sendiri; Jika mempunyai waktu dan ketrampilan kenapa tidak melakukan proses daur ulang sendiri. Dengan kreatifitas berbagai sampah yang telah terkumpul dan dipilah dapat disulap menjadi barang-barang baru yang bermanfaat.

\section{Keuntungan Daur Ulang Sampah Anorganik}

A. Aspek Lingkungan

Penghematan Sumber Daya Alam.

Pemenuhan bahan baku pabrik dari hasil pemulungan sampah menyebabkan penggunaan bahan baku yang berasal dari alam menjadi berkurang dan dapat ditekan. Selanjutnya bahan baku dari alam dapat digunakan untuk proses produksi yang memiliki nilai tambah lebih tinggi. Sebagai contoh, setiap ton daur-ulang baja dapat menghemat 1,5 ton biji besi dan 3,6 barel minyak atau menghemat $67 \%$ energi.
Beberapa keunggulan daur-ulang sampah anorganik yang berkaitan dengan penanggulangan pencemaran lingkungan antara lain adalah sebagai berikut: a. Mendaurulang 1 ton kertas koran akan menyelamatkan 17 pohon dan menggunakan kertas daur-ulang dapat mengurangi $74 \%$ pencemaran udara, $34 \%$ pencemaran air, dan menghemat energi hingga $67 \%$. b. Usaha daur-ulang sampah anorganik seperti kaca, plastik, kertas koran, kaleng, besi, dapat mengurangi tumpukan sampah kota hingga $25 \%$.

\section{B. Aspek Ekonomi}

Menghemat Biaya Operasional Pengelolaan Sampah

Daur-ulang sampah anorganik telah terbukti dapat mereduksi biaya pengangkutan dan pembuangan akhir. Sebagai contoh, di Bandung laju daur-ulang sampah anorganik di 38 TPS yang ada adalah sekitar $37.204 \mathrm{~kg}$ per minggu atau $1.939 .923 \mathrm{~kg}$ per tahun. Biaya satuan pengangkutan dan pembuangan akhir untuk setiap ton sampah di Kota Bandung adalah sebesar Rp.58.540,- dan Rp.17.700,-, maka biaya pengelolaan sampah yang dapat dihemat bisa mencapai Rp. 147 juta setiap tahun. Bila diasumsikan laju daur-ulang sampah anorganik meningkat sampai 20\% dari total sampah anorganik yang masuk ke TPS, maka biaya yang dapat dihemat mencapai $\mathrm{Rp}$. 379 juta per tahun.

\section{KESIMPULAN}

Daur ulang adalah proses tuk menjadikan suatu bahan bekas menjadi bahan baru dengan tujuan mencegah adanya sampah yang sebenarnya dapat menjadi sesuatu yang berguna, mengurangi penggunaan bahan baku yang baru, mengurangi penggunaan energi, mengurangi polusi, kerusakan lahan, dan emisi gas rumah kaca jika dibandingkan dengan proses pembuatan barang baru. Daur ulang adalah salah satu strategi pengelolaan sampah padat yang terdiri atas kegiatan pemilahan, pengumpulan, pemrosesan, pendistribusian 
dan pembuatan produk / material bekas pakai, dan komponen utama dalam manajemen sampah modern dan bagian ketiga adalam proses hierarki sampah 3R (Reuse, Reduce, andRecycle).

Material yang bisa didaur ulang terdiri dari sampah kaca, plastik, kertas, logam, tekstil, dan barang elektronik. Meskipun mirip, proses pembuatan kompos yang umumnya menggunakan sampah biomassa yang bisa didegradasi oleh alam, tidak dikategorikan sebagai proses daur ulang. Daur ulang lebih difokuskan kepada sampah yang tidak bisa didegradasi oleh alam secara alami demi pengurangan kerusakan lahan. Secara garis besar, daur ulang adalah proses pengumpulan sampah, penyortiran, pembersihan, dan pemrosesan material baru untuk proses produksi.

\section{DAFTAR PUSTAKA}

Apriadji, Wied Harry.1994. Memproses sampah. Jakarta: Penebar Swadaya.

Suhadi. 1995. Wiraswasta Sampah. Surabaya: Bina Ilmu. 